\title{
Protection against the allergic airway inflammation depends on the modulation of spleen dendritic cell function and induction of regulatory T cells in mice
}

\author{
Yaoli Wang 1,2,3, Chunxue Bai2, Guansong Wang1 , Diane Wang, Xiaoming Cheng'1, Jian Huang, Dongpo Jiang, \\ Guisheng Qian ${ }^{1}$ and Xiangdong Wang*2
}

\begin{abstract}
Background: Allergen-induced imbalance of specific T regulatory (Treg) cells and T helper 2 cells plays a decisive role in the development of immune response against allergens.

Objective: To evaluate effects and potential mechanisms of DNA vaccine containing ovalbumin (OVA) and Fc fusion on allergic airway inflammation.

Methods: Bronchoalveolar lavage (BAL) levels of inflammatory mediators and leukocyte infiltration, expression of $\mathrm{CD}_{11 c}{ }^{+} \mathrm{CD}_{80}{ }^{+}$and $\mathrm{CD}_{11 c}{ }^{+} \mathrm{CD}_{86}{ }^{+}$CO-stimulatory molecules in spleen dendritic cells (DCs), circulating $\mathrm{CD}_{4}{ }^{+}$and $\mathrm{CD}_{8}{ }^{+} \mathrm{T}$ cells, Foxp3 ${ }^{+}$in spleen $\mathrm{CD}_{4}{ }^{+} T$ cells and spleen $\mathrm{CD}_{4}{ }^{+} T$ cells were measured in OVA-sensitized and challenged animals pretreated with pcDNA, OVA-pcDNA, Fc-pcDNA, and OVA-Fc-pcDNA.

Results: OVA-Sensitized and challenged mice developed airway inflammation and Th2 responses, and decreased the proliferation of peripheral $\mathrm{CD}_{4}{ }^{+}$and $\mathrm{CD}_{8}{ }^{+} \mathrm{T}$ cells and the number of spleen Foxp ${ }_{3}{ }^{+}$Treg. Those changes with increased INF- $\gamma$ production and reduced OVA-specific IgE production were protected by the pretreatment with OVA-Fc-pcDNA. Conclusion: DNA vaccine encoding both Fc and OVA showed more effective than DNA vaccine encoding Fc or OVA alone, through the balance of DCs and Treg.
\end{abstract}

\section{Introduction}

Allergic asthma is a Th2 lymphocyte-associated inflammatory airway disease characterized by airway eosinophilia, goblet-cell hyperplasia, variable airway obstruction and hyper-responsiveness [1]. The balance between allergen-specific $\mathrm{T}$ regulatory (Treg) cells and $\mathrm{T}$ helper 2 cells appears to be decisive in the development of the immune response against allergens [2]. Allergen-specific immunotherapy (SIT) has been suggested as one of the few antigen-specific treatments for inflammatory diseases, with a long-term of efficacy [2]. SIT could reduce the development of asthma and bronchial responses in patients exposed to inhaled allergens. It is possible to target anti-inflammatory therapy to the various pathways of the disease, improving asthma control. However, the

* Correspondence: xiangdong.wang@telia.com

2 Department of Pulmonary Medicine, Zhongshan Hospital, Fudan University, Shanghai, China

Full list of author information is available at the end of the article mechanisms by which allergen-DNA-targeted dentritic cells (DCs) plays anti-inflammatory roles remain unclear.

We found that allergen-DNA-targeted DCs reduced Th2 responses and the expression of $\mathrm{C}$ co-stimulatory molecules like $\mathrm{D}_{11 \mathrm{c}}{ }^{+} \mathrm{CD}_{80}{ }^{+}$and $\mathrm{CD}_{11 \mathrm{c}}{ }^{+} \mathrm{CD}_{86}{ }^{+}$in experimental asthma [3]. The present study furthermore investigated the potential mechanisms where Treg cells and spleen DCs may be involved in the therapeutic process of DNA vaccination coding with $\mathrm{Fc}$ and ovalbumin (OVAFc-DNA) in in allergic models. We determine the therapeutic role of immunization with OVA-Fc-DNA-targeted DCs and ascertain the roles of spleen DCs in the protection.

\section{Methods}

Animals

Male BALB/c mice, 6-10 weeks old at the onset of experiments, were purchased from Institute of Animal in Third 
Military Medical University (Chongqing, China). Animal care and experimental procedures were in accordance with the animal ethics regulations of the Home Office, UK.

\section{Construction of OVA-Fc-pcDNA 3.1 $_{\text {immunization vector }}$}

To construct the DNA vaccine containing OVA and Fc fusion gene targeting DCs, the murine OVAcDNA was amplified from OVA-pcDNA3.1 plasmid by polymerase chain reaction $(\mathrm{PCR})$, spliced and then cloned into pMIgV containing murine IgG2a Fc cDNA. OVA-FcpcDNA3.1 plasmid was finally constructed after subcloning spliced OVA-Fc into pcDNA 3.1 plasmid. OVA-FcpcDNA3.1 plasmids were then transfected into $\mathrm{CHO}$ cells with lipofectamine. The expression of OVA and Fc was determined by flow cytometry, Western blotting, and enzyme-linked immunosorbent assay (ELISA). DNA sequencing and restriction endonuclease digestion analysis indicated that the eukaryotic expression vector OVAFc-pcDNA ${ }_{3.1}$ had been constructed successfully. The expression of OVA and Fc expression could be detected in $\mathrm{CHO}$ cells by Western blotting, ELISA, and flow cytometry, as shown in Fig. 1A and 1B. The PCR products of OVA and Fc were selected as target DNA frag- ments and cloned into $\mathrm{pcDNA}_{3.1}(+)$ to construct the recombinant plasmids OVA-pcDNA 3.1 and OVA-Fc$\mathrm{pcDNA}_{3.1}$ respectively. The plasmids were propagated in Escherichia coli and large scale purification of all plasmids was conducted with the EndoFree Plasmid Giga Kit (Qiagen, Mississauga, Canada) according to the manufacturer's instructions.

\section{Immunization protocols}

BALB/c mice (8-wk-old, male, 20 25 g) were maintained under standard conditions with free access to water and rodent laboratory food. Mice were handled according to experimental procedures involving mice [4]. Mice were divided randomly into the following groups, A: PBS or plasmid- vaccinated mice sensitized and challenged with PBS, B: PBS- vaccinated mice sensitized and challenged with OVA, C: pcDNA $_{3.1}$ plasmid-vaccinated mice sensitized and challenged with OVA, D: OVA- pcDNA $_{3.1}$ plasmid-vaccinated mice sensitized and challenged with OVA, and E: OVA-Fc-pcDNA 3.1 plasmid-vaccinated mice sensitized and challenged with OVA ( $\mathrm{n}=8$ per group). $\mathrm{BALB} / \mathrm{c}$ mice were injected intramuscularly with $100 \mu \mathrm{g}$ of PBS, pcDNA, OVA-pcDNA and OVA-Fc-DNA in a final volume of $100 \mu \mathrm{l} 0.9 \% \mathrm{NaCl}$ on day 0 and boosted

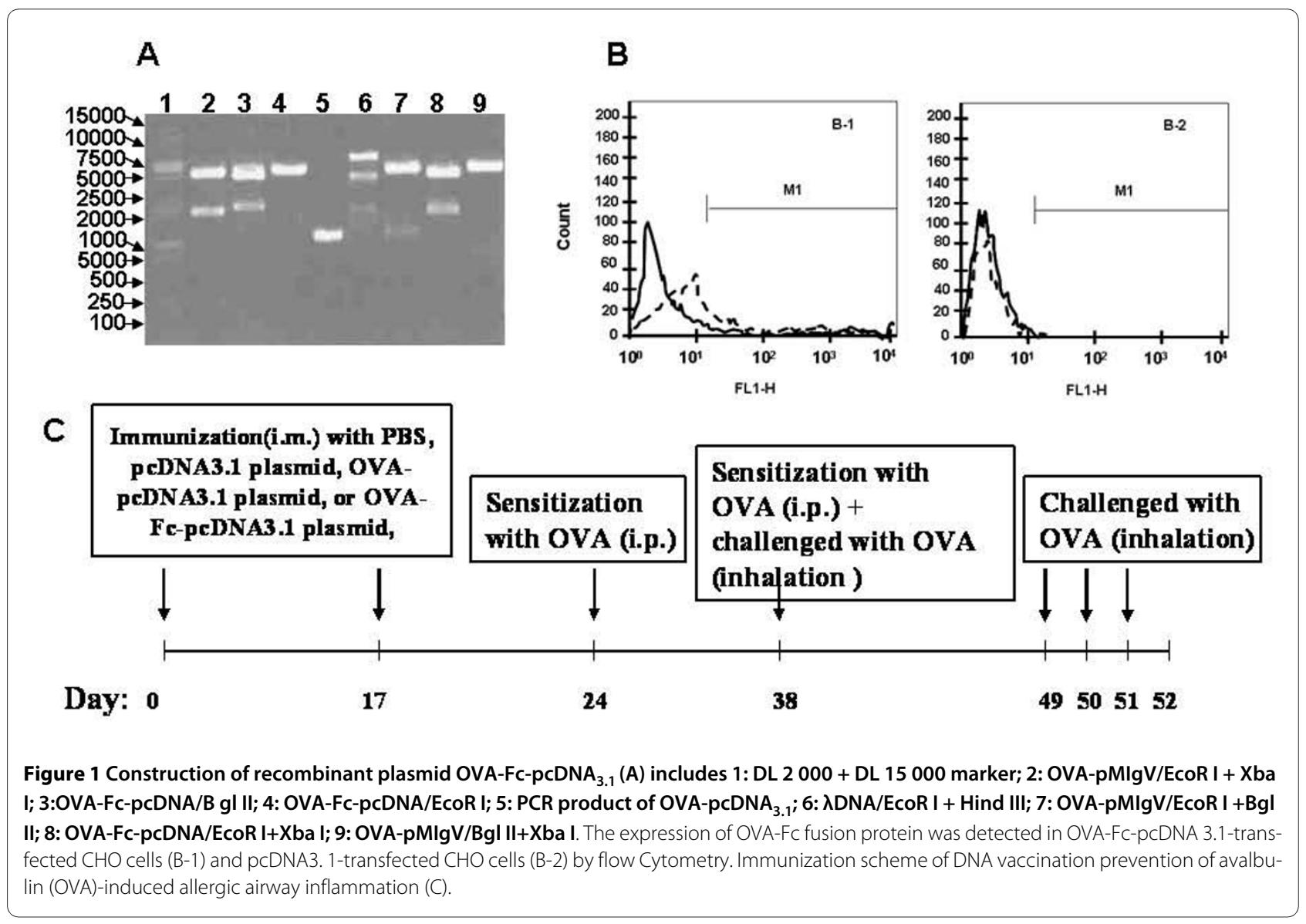


intramuscularly with the same amount of plasmid DNA. The mice were then sensitized to OVA for the induction of allergic asthma in BALB/c mice, as described previously [5]. OVA (grade V, $50 \mathrm{mg}$ ) adsorbed to $2 \mathrm{mg}$ aluminum potassium sulfate (alum) was administered intraperitoneally on days 24 and 38, followed by an inhalation of 1\% OVA (grade II) diluted in PBS for $30 \mathrm{~min}$ on days $38,49,50$, and 51, respectively. Control mice received the same processes with OVA and an inhalation of PBS for $30 \mathrm{~min}$ and experimental design was shown in Fig. 1C. Twenty four hours after the last challenge (day 52), mice were sacrificed, blood was taken, bronchoalveolar lavage (BAL) was performed, lungs were removed and fixed, and spleen DCs and $\mathrm{CD}_{4}{ }^{+} \mathrm{T}$ cells were isolated for in vitro culture.

\section{Determination of OVA- specific lgE levels in serum}

Serum levels of OVA-specific IgE were determined by ELISA. Briefly, 96 microtiter plates were coated overnight with $100 \mu \mathrm{l}$ of OVA $(10 \mu \mathrm{g} / \mathrm{ml}$ in $0.1 \mathrm{~mol}$ carbonate buffer, $\mathrm{pH} 9.6)$ at $4{ }^{\circ} \mathrm{C}$. The antigen-coated plates were washed with PBST (0.5\% Tween-20 in PBS) thrice. Mouse sera were added and the plates were incubated with peroxidase-conjugated anti-mouse IgE antibody (Southern Biotech, USA) at $4^{\circ} \mathrm{C}$ overnight, and then washed with PBST thrice before adding citric acid-phosphate buffer ( $\mathrm{pH}$ 5.0) containing $0.5 \mathrm{mg} / \mathrm{ml}$ of O-phenylenediamine (Sigma, USA). Color was developed at $37^{\circ} \mathrm{C}$ and measured at 450 $\mathrm{nm}$ after the reaction was stopped with sulfuric acid at 2.5 $\mathrm{mol} / \mathrm{L}$.

\section{Bronchoalveolar lavage}

The trachea were exposed, cannulated and gently instilled with $500 \mu \mathrm{l}$ of cold PBS twice. The volume, total cell number and composition of BAL samples were recorded. Samples were centrifuged ( $\times 500 \mathrm{~g}$ for $5 \mathrm{~min}$ utes at $4^{\circ} \mathrm{C}$ ), resuspended and cytospined onto slides. Different cells from each sample were counted for 200 cells in duplicate on coded slides. BAL fluid was stored at $70^{\circ} \mathrm{C}$ and levels of the cytokines interleukin (IL)-4, IL-5 and interferon (INF) $-\gamma$ were determined using specific ELISA according to the use's manual (ELISA kits, eBioscience).

\section{Histological evaluation}

Twenty-four hours after the last allergen challenge, lungs were harvested, fixed in 10\% neutral-buffered formalin and embedded in paraffin. Sections $(5 \mu \mathrm{m})$ of specimens were put onto 3-amino propyltriethoxy silane 3-Aminopropyltriethoxysilane-coated slides. The tissues were assessed for morphology and cellular infiltration using haematoxylin and eosin (H\&E) staining. The degree of cellular infiltration was scored as described previously [6]. Inflammatory changes were graded by histopatholog- ical assessment using a semiquantitative scale of 0-5 for perivascular eosinophilia, bronchiolar eosinophilia, epithelial damage and oedema.

\section{Generation of DCs from spleen and culture}

Spleen DCs were enriched as described previously [7]. Briefly, after the spleen was disrupted, the cells were centrifuged at $1300 \mathrm{rpm}$ for $5 \mathrm{~min}$, resuspended in RPMI 1640 medium supplemented with $10 \%$ heat-activated fetal calf serum, $2 \mathrm{mmol} / \mathrm{l} \mathrm{L}$-glutamine, $1 \mathrm{mmol} / \mathrm{l}$ pyruvate, $50 \mu \mathrm{mol} / \mathrm{l}$ mercaptoethanol, $100 \mathrm{U} / \mathrm{ml}$ penicillin, and $100 \mu \mathrm{g} / \mathrm{ml}$ streptomycin, and then incubated in plastic cell cultures plates for $2 \mathrm{~h}$ at $37^{\circ} \mathrm{C}$ in a $5 \% \mathrm{CO}_{2}$ atmosphere. Culture plates were then washed thrice with RPMI 1640 medium and nonadherent cells were discarded. The residual adherent cells were maintained in the culture medium and incubated overnight at $37^{\circ} \mathrm{C}$ in a 5\% CO2 atmosphere. After incubation, DCs with the adherence capacity in the first hours of culture become nonadherent and float in the medium. The DCs were collected and immediately used in the assays.

\section{Detection of $\mathrm{CD}_{11 \mathrm{c}}+\mathrm{CD}_{80}+$ and $\mathrm{CD}_{11 \mathrm{c}}+\mathrm{CD}_{86}+$ surface markers on spleen DCs}

DCs were harvested from the spleen, incubated with FITC-labeled $\mathrm{CD}_{11 \mathrm{c}}$ (eBioscience Inc.), PE-labeled anti$\mathrm{CD}_{80}$ (B7-1) $\mathrm{mAb}$ (eBioscience Inc.), and PE-labeled anti$\mathrm{CD}_{86}$ (B7-2) mAb (Southernbiotech) on ice for $30 \mathrm{~min}$, and washed with PBS thrice. Ten thousand cells were collected from each sample and the data were analyzed with flow cytometer and CELLQUEST software (Coulter, Becton Dickinson, USA). For the DC marker staining, DCs were incubated with FITC-labeled rat anti-mouse IgG as isotype control on ice for $30 \mathrm{~min}$ and washed. The expression of the costimulatory molecules, i.e. $\mathrm{CD}_{11 \mathrm{c}}{ }^{+} \mathrm{CD}_{80}{ }^{+}$and $\mathrm{CD}_{11 \mathrm{c}}{ }^{+} \mathrm{CD}_{86}{ }^{+}$, surface markers on spleen DCs detected by FACS.

\section{Detection of peripheral $\mathrm{CD}_{4}+$ and $\mathrm{CD}_{8}{ }^{+} \mathrm{T}$ cells}

Blood from mice was transferred into $6 \times 50 \mathrm{ml}$ Falcon tubes using a $50 \mathrm{ml}$ stripette and centrifuged at $1800 \mathrm{rpm}$ for $5 \mathrm{~min}$. The supernatant was aspirated and pooled into two of the tubes with PBS for a total volume of $75 \mathrm{ml}$. The $15 \mathrm{ml}$ of Ficoll Paque was placed into three $50 \mathrm{ml}$ tubes/ group.

$25 \mathrm{ml}$ of the diluted filter material was transferred onto the Ficoll Paque so that they form two separate layers. After the centrifugation at $1800 \mathrm{rpm}$ for $20 \mathrm{~min}$, the leukocytes can now be collected at the interphase between the Ficoll Paque and the plasma. The $\mathrm{CD}_{4}{ }^{+}$and $\mathrm{CD}_{8}{ }^{+} \mathrm{T}$ cells were isolated from the peripheral blood were detected by flow cytometry. After autologous $\mathrm{CD}_{4}{ }^{+}$and $\mathrm{CD}_{8}{ }^{+} \mathrm{T}$ cells were stimulated with the targeted DCs, the 
proliferation and cytokine production were measured. Flow-cytometry assay was carried to detect the numbers of peripheral $\mathrm{CD}_{4}{ }^{+}$and $\mathrm{CD}_{8}{ }^{+} \mathrm{T}$ cells in mice $24 \mathrm{~h}$ after the last OVA challenge, using FITC-labeled $\mathrm{CD}_{4}{ }^{+}$and $\mathrm{CD}_{8}{ }^{+}$ $\mathrm{mAb}$, hemolytic agent( BD PharMingen) and IgG2a (Sero Tec).

\section{Detection of Foxp ${ }_{3}{ }^{+}$Tregs in spleen $\mathrm{CD}_{4}{ }^{+} \mathrm{T}$ cells}

We harvested $\mathrm{CD}_{4}{ }^{+} \mathrm{T}$ cells of spleen from the various groups using antibody-coated paramagnetic MultiSort MicroBeads (MACS, Miltenyi Biotec, Bergisch Gladbach, Germany) according to the manufacturers protocol. After detaching, $\mathrm{CD}_{4}{ }^{+} \mathrm{T}$ cells were stained with $\mathrm{CD}_{25}$ MicroBeads (Miltenyi Biotec) and $\mathrm{CD}_{4}{ }^{+} \mathrm{CD}_{25}{ }^{+} \mathrm{T}$ cells were positively and negatively selected. Separation was controlled by FCM and Spleen $\mathrm{CD}_{4}{ }^{+} \mathrm{T}$ cells were labeled with Mouse Regulatory $\mathrm{T}$ cell Staining Kit to detect the expression of Foxp ${ }_{3}{ }^{+}$in spleen $\mathrm{CD}_{4}{ }^{+} \mathrm{T}$ cells (eBioscience Inc.).

\section{Statistical analysis}

Data were expressed with means \pm SD. Difference between groups was analyzed using software SPSS for windows (version 8.0) by unpaired two-tailed parametric Student's $t$-test or ANOVA test. $P$-values less than 0.05 were considered statistically significant.

\section{Results}

Histological analysis demonstrated that significant airway inflammation was observed in OVA-sensitized and challenged animals vaccinated with $\mathrm{PBS}$ or $\mathrm{pcDNA}_{3.1}$ plasmid, but less with OVA- pcDNA ${ }_{3.1}$ or OVA-Fc-pcDNA ${ }_{3.1}$ vaccination. The severity of leukocyte infiltration around the central bronchi, alveoli and blood vessels was scored and shown in Fig. 2. Leukocyte infiltration of the lungs was reduced by vaccination with OVA plasmid compared to vector alone. The thickness of small airway walls and the number of infiltrated eosinophils around the airway increased, eosinophils appeared within the lumen of the airway, and goblet cell hyperplasia and hypertrophy occurred in OVA-sensitized and challenged animals vaccinated with PBS (Fig. 2B) or pcDNA ${ }_{3.1}(\mathrm{C})$, as compared with those sensitized and challenged with PBS (A). OVA challenge led to a dense inflammatory infiltrate of lymphocytes, mononuclear and eosinophils as well as to epithelial shedding, which was partially prevented by immunization with $\mathrm{pcDNA}_{3.1}$ or OVA- $\mathrm{pcDNA}_{3.1}$ (Fig. 2D) and obviously by OVA-Fc-pcDNA ${ }_{3.1}$ (Fig. 2E).

As shown in Fig. 3A, serum levels of OVA-specific IgE were significantly higher in OVA-sensitized and challenged mice vaccinated with PBS, as compared with these sensitized, challenged and vaccinated with PBS ( $p<0.01$,

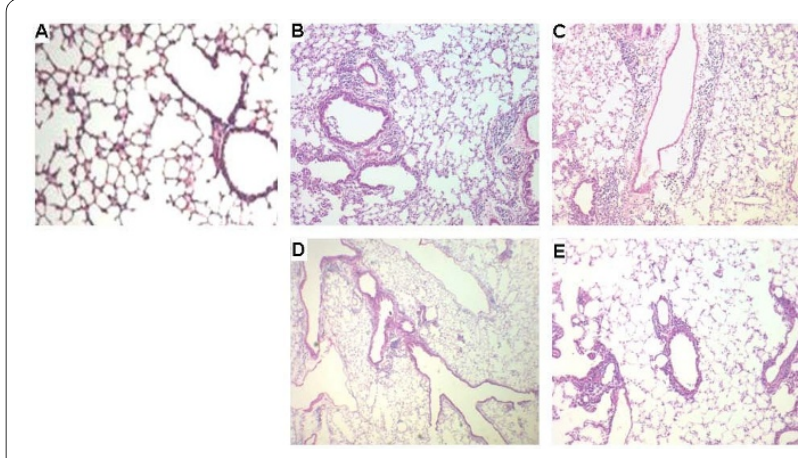

Figure 2 Histological findings of peripheral airway tissues (H\&E, $\times 100$ origin) in PBS-vaccinated mice sensitized and challenged with PBS (A), PBS-vaccinated mice sensitized and challenged with ovalbumon (OVA) (B), pcDNA . $_{3.1}$-vaccinated mice sensitized and challenged with OVA (C), OVA- pcDNA . $_{3.1}$-vaccinated mice sensitized and challenged with OVA (D), and OVA-Fc-pcDNA 3.1 $^{-}$ vaccinated mice sensitized and challenged with OVA (E)

Fig. 3A). OVA-sensitized and challenged animals vaccinated with OVA-Fc-pcDNA 3.1 had significantly lower levels of OVA-specific IgE, as compared with those vaccinated with $\mathrm{PBS}$ or $\mathrm{pcDNA}_{3.1}(\mathrm{p}<0.05)$. Animal vaccinated with pcDNA ${ }_{3.1}$ plasmid had similar levels of

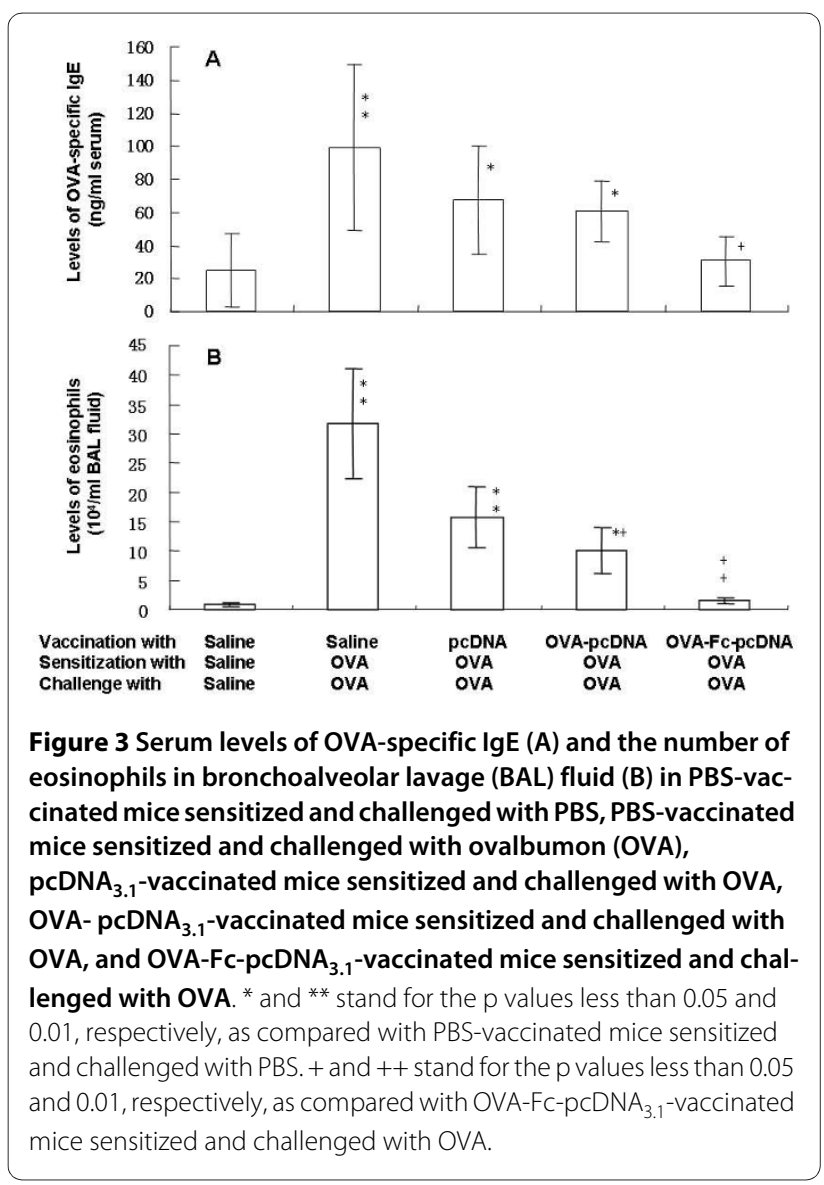


OVA-specific IgE with those vaccinated with OVA$\mathrm{pcDNA}_{3.1}$. The number of eosinophils in BAL fluid of OVA mice vaccinated with PBS or pcDNA 3.1 was significantly higher than those without OVA ( $<<0.01$, Fig. 3B). Immunization with OVA-Fc-pcDNA ${ }_{3.1}$ significantly prevented OVA-induced eosinophilia in BAL fluid, as compared with that with PBS, $\mathrm{pcDNA}_{3.1}$ or OVA-pcDNA 3.1 (p $<0.01$ or 0.05 , respectively). Vaccination with OVA$\mathrm{pcDNA}_{3.1}$ partially prevented from OVA-increased number of eosinophils ( $\mathrm{p}<0.05$, vs PBS or $\mathrm{pcDNA}_{3.1}$, respectively). OVA induced a significant elevation of IL-4 BAL fluid in all animals, as compared with animals without OVA ( $p<0.01$ or 0.05 , respectively, Fig. 4 A), while OVAFc-pcDNA 3.1 showed partially preventive effects ( $\mathrm{p}<$ 0.05 , vs OVA animals vaccinated with PBS). The BAL levels of IL-5 in OVA animals vaccinated with PBS, pcDNA $_{3.1}$ or Fc-pcDNA ${ }_{3.1}$ were significantly higher than those without OVA, which was significantly prevented by OVA-Fc-pcDNA ${ }_{3.1}$, as compared with pcDNA ${ }_{3.1}$ or Fc-pc ( $p<0.01$, respectively, Fig. 4B). Immunization with OVAFc-pcDNA ${ }_{31}$ also significantly prevented OVA-reduced level of INF- $\gamma$ in BAL fluid, as immunization with PBS or $\mathrm{pcDNA}_{3.1}$ ( $\mathrm{p}<0.05$, Fig. $4 \mathrm{C}$ ).

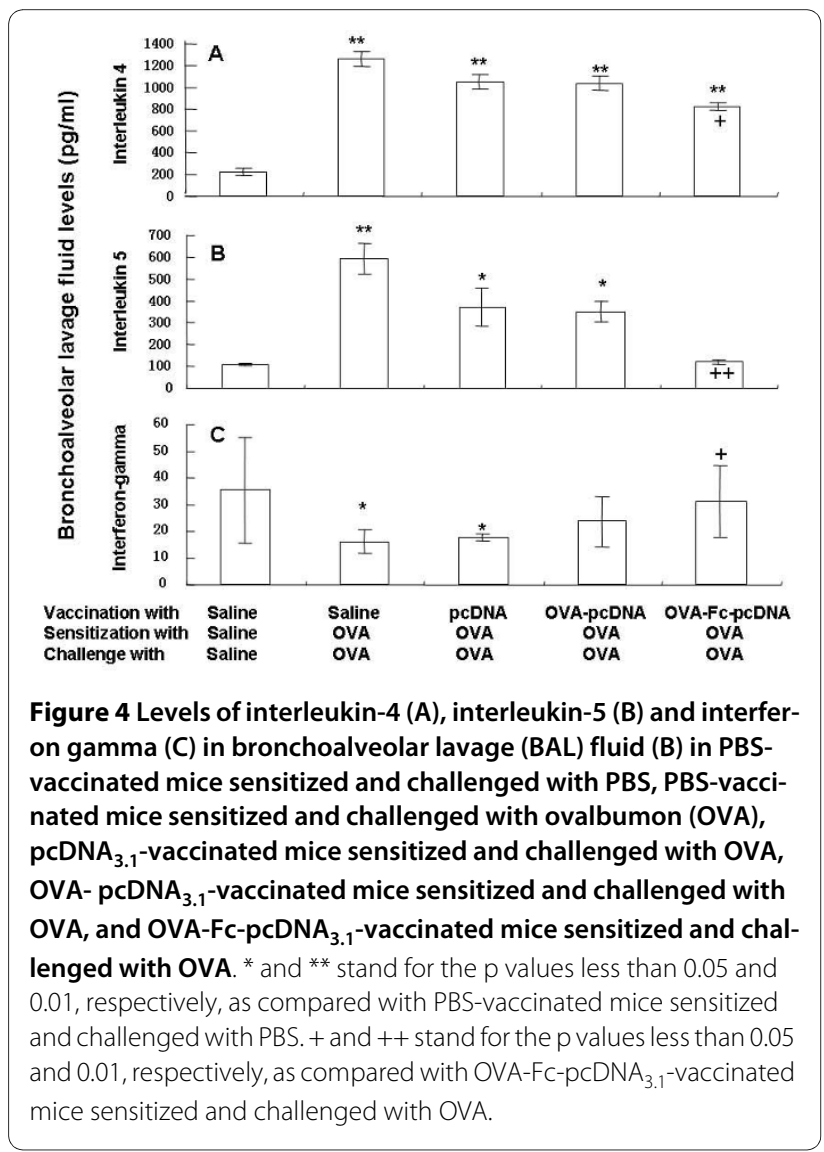

We isolated spleen-derived DCs from all animals, identified the characteristics of these DCs expressed $C_{11 c}$ molecule, detected OVA-increased expression of $\mathrm{CD}_{80}{ }^{+}$ and $\mathrm{CD}_{86}{ }^{+}$on DCs obtained from the spleen, and then evaluated the preventive effects of OVA-Fc-pcDNA ${ }_{3.1}$ on the expression of $\mathrm{CD}_{80}{ }^{+}$and $\mathrm{CD}_{86}{ }^{+}$on DCs obtained from the spleen of OVA-sensitized and challenged mice. OVA induced a significant expression of $\mathrm{CD}_{11 \mathrm{c}}{ }^{+} \mathrm{CD}_{80}{ }^{+}$(Fig. 5A) and $\mathrm{CD}_{11 \mathrm{c}}{ }^{+} \mathrm{CD}_{86}{ }^{+}$(Fig. 5B) on spleen DCs harvested from mice vaccinated with PBS or $\mathrm{pcDNA}_{3.1}$, as compared with those without OVA $(\mathrm{p}<0.05)$, which was significantly prevented by the vaccination with OVA-Fc-pcDNA 3.1 .

Our pilot study showed that targeted DCs stimulated the proliferation of peripheral $\mathrm{CD}_{4}{ }^{+} \mathrm{T}$ and $\mathrm{CD}_{8}{ }^{+} \mathrm{T}$ cells in a concentration-dependent pattern. The proliferation of both peripheral $\mathrm{CD}_{8}{ }^{+}$(Fig. 6A) and $\mathrm{CD}_{4}{ }^{+} \mathrm{T}$ cells (Fig. 6B) in OVA mice vaccinated with $\mathrm{PBS}$ or $\mathrm{pcDNA}_{3.1}$ was significantly lower than those without OVA $(\mathrm{p}<0.01$ or 0.05 , respectively). Vaccination with OVA-Fc-pcDNA 3.1 significantly prevented OVA-suppressed cell proliferation $(\mathrm{p}<0.05)$. The expression of Foxp ${ }_{3}{ }^{+}$on spleen $\mathrm{CD}_{4}{ }^{+} \mathrm{T}$ cells were significantly suppressed by OVA mice vaccinated with PBS, pcDNA 3.1 and Fc-pcDNA 3.1 ( $p<0.01$, respectively, Fig. $6 \mathrm{C}$ ), but not with OVA-Fc-pcDNA 3.1 .

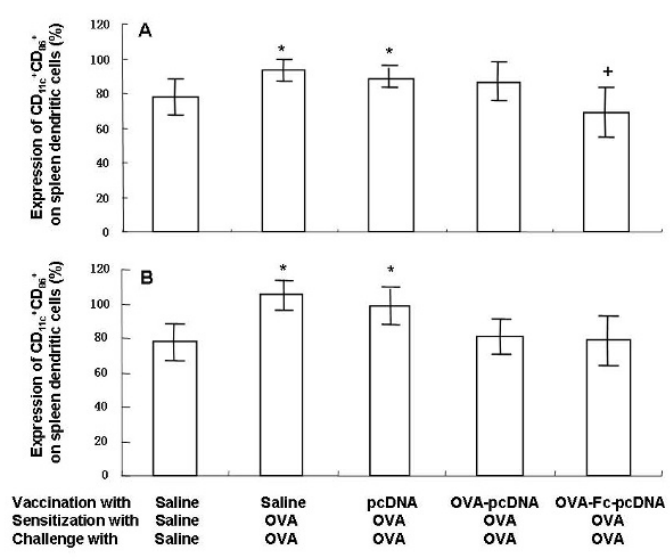

Figure 5 Expression of $C D_{11 c}+C D_{80}+(A)$ and $C D_{11 c}+C D_{86}{ }^{+}(B)$ on spleen dendritic cells harvested from PBS-vaccinated mice sensitized and challenged with PBS, PBS-vaccinated mice sensitized and challenged with ovalbumon (OVA), pcDNA ${ }_{3.1}$-vaccinated mice sensitized and challenged with OVA, OVA- pCDNA $_{3.1}$-vaccinated mice sensitized and challenged with OVA, and OVA-FCpcDNA $_{3.1}$-vaccinated mice sensitized and challenged with OVA. * stands for the $p$ values less than 0.05 , as compared with PBS-vaccinated mice sensitized and challenged with PBS. + stands for the $p$ values less than 0.05, as compared with OVA-Fc-pcDNA 3.1 -vaccinated mice sensitized and challenged with OVA. 


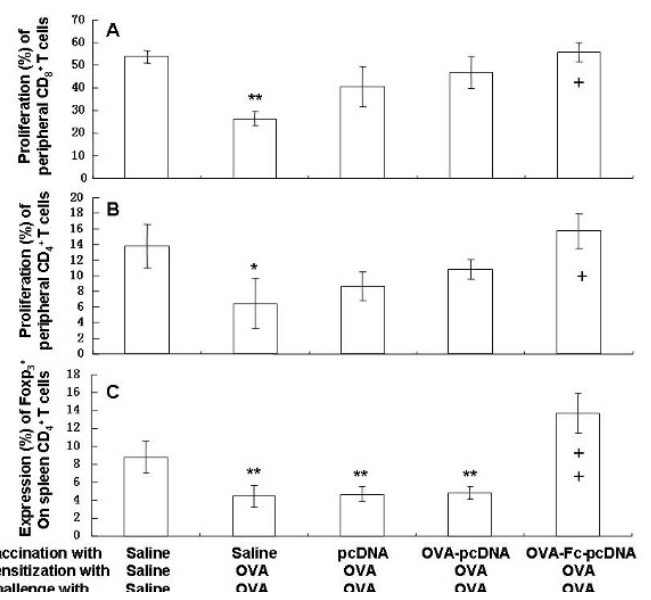

Figure 6 Proliferation of peripheral $\mathrm{CD}_{4}+(\mathrm{A})$ and $\mathrm{CD}_{8}+\mathrm{T}$ cells (B) and the expression of Foxp ${ }_{3}{ }^{+}$on spleen $\mathrm{CD}_{4}+\mathrm{T}$ cells $(C)$ harvested from PBS-vaccinated mice sensitized and challenged with PBS, PBS-vaccinated mice sensitized and challenged with ovalbumon (OVA), pcDNA . $_{3.1}$-vaccinated mice sensitized and challenged with OVA, OVA- pcDNA 3.1 -vaccinated mice sensitized and challenged

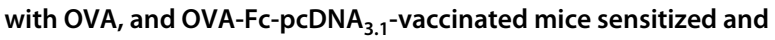
challenged with OVA. ${ }^{*}$ and ${ }^{* *}$ stand for the $p$ values less than 0.05 and 0.01 , respectively, as compared with PBS-vaccinated mice sensitized and challenged with PBS. + and ++ stand for the $p$ values less than 0.05 and 0.01 , respectively, as compared with OVA-Fc-pcDNA ${ }_{3.1^{-}}$ vaccinated mice sensitized and challenged with OVA.

\section{Discussion}

The results from the present study demonstrated that allergen-DNA-targeted DCs were highly effective in preventing allergen-induced airway inflammation in a murine allergic model. OVA-sensitization and challenge could induced the development of airway inflammation and Th2 responses and suppressed the proliferation of peripheral $\mathrm{CD}_{4}{ }^{+}$and $\mathrm{CD}_{8}{ }^{+} \mathrm{T}$ cells and the expression of Foxp $_{3}{ }^{+}$Treg in spleen, which could be prevented by the vaccination with OVA-Fc-pcDNA 3.1 . The potential mechanisms of OVA-Fc-pcDNA ${ }_{3.1}$ effects may be that Fc enhancing $\mathrm{DC}$ absorption is more powerful in stimulating the production of $\mathrm{T}_{\mathrm{H}} 1$ cytokine synthesis in naïve and memory T cells.

As an alternative to the administration of allergens or allergen derivatives, vaccination with allergen-encoding DNA has been proposed as a strategy for SIT [8-10]. Dendritic cells are uniquely situated in the immune cascade to initiate and modulate airway immune responses [1113]. In addition, immature DCs express a number of specific chemokine receptors, FcR, and Toll-like receptors, through which the DCs are developing [14-16]. DCs can be activated or inhibited through FcR by antibodies or immune complex formed by antibodies depending on the variations of FcR engaged. Activating and inhibitory IgG Fc receptors on DCs mediate opposing functions $[17,18]$ DNA vaccination may directly target DCs involved in allergen-specific $\mathrm{T}_{\mathrm{H}}$ 1-cell responses, showing preventive effects when delivered in mice [19-23]. The vaccination with OVA-pcDNA ${ }_{3.1}$ or OVA-Fc-pcDNA 3.1 showed preventive effects on OVA-induced hyper-production of IL4 and IL-5 and hypo-production of INF- $\gamma$, and eosinophil infiltration, while the effects of OVA-Fc-pcDNA ${ }_{3.1}$ were more significant. Our study suggested that DNA vaccine encoding both mouse Fc and OVA was more effective than DNA vaccine encoding only OVA in suppressing airway inflammation.

We found that local exposure to OVA resulted in an increased number of spleen DCs expressing $C D_{11 c}{ }^{+} C_{80}$ and $\mathrm{CD}_{11 \mathrm{c}}{ }^{+} \mathrm{CD}_{86}$ molecules, similar to the previous findings [24], suggesting that $C D_{80}$ and $C D_{86}$ molecules act as the regulators of immune responses. The $\mathrm{CD}_{80}$ and $C \mathrm{D}_{80}$, as the most important costimulatory molecules, could play the important role in the allergic immune responses, indicating that the effective cross-presentation and DC maturation should be considered in the development of efficacious targeting strategies. Our results also showed that OVA-induced Tregs decrease could also be prevented by the allergen-DNA-targeted-DCs, suggesting that the allergen-DNA-targeted-DC may be useful in SIT and the restoration of Tregs played a key role in successful SIT.

Costimulatory molecules as potential targets contribute to the therapeutic intervention in allergic airway disease, which could be treated with DCs activated by crosslinking B7-DC [25-28]. Spleen DCs function could be modulated following SIT. Immune complexes of IgG and antigen can be internalized via FcRs on DC, resulting in $\mathrm{DC}$ maturation and priming of antigen-specific $\mathrm{CD}_{8}+\mathrm{T}$ cells in vivo[29,30]. However, DCs express both activating and inhibitory FcRs, and the balance between activating and inhibitory signaling will determine whether uptake of immune complexes results in naive $\mathrm{T}$ cell activation and protective immunity [31]. The OVA-Fc-pcDNA ${ }_{3.1}$ influenced those surface marker expressions on targeted DCs, probably down-regulating general capability of DCs to present antigen [32-34]. Spleen DCs have a partially mature phenotype and express a range of co-stimulatory molecules that are intermediate between immature and mature DCs, resulting in tolerogenic interaction with $\mathrm{T}$ cells in SIT. We found that the combination of DNA vaccination with Fc and OVA had better effects onOVAinduced alterations in the spleen. It is evidenced by the previous findings that DNA vaccination suppressed both Th1 and Th2 responses (IFN- $\gamma$ and IL-4 production from spleen cells) [34-36]. It would be more interesting to explore the potential mechanisms of $\mathrm{CD}_{11 \mathrm{c}}{ }^{+} \mathrm{CD}_{80}$ and $\mathrm{CD}_{11 \mathrm{c}}{ }^{+} \mathrm{CD}_{86}$ induction and regulation between DCs and Tregs in the further studies. 
A great number of studies have shown that the targeting of antigens to DC surface receptors elicits effective immune responses [37-42], although it is still questionable that the certain surface receptors can make more suitable targets than others. Immunization with OVA-Fc$\mathrm{pcDNA}_{3.1}$ could prevent OVA-induced over-formation of allergen-specific IgE, local hyper-production of IL-4 and IL-5 and hypo-production of INF- $\gamma$, over-expression of costimulatory molecules $\mathrm{CD}_{11 \mathrm{c}}{ }^{+} \mathrm{CD}_{80}{ }^{+}$and $\mathrm{CD}_{11 \mathrm{c}}{ }^{+} \mathrm{CD}_{86}{ }^{+}$in spleen, and finally airway inflammation. Thus, DNA vaccine encoding OVA directly to DCs may a new alternative of therapies for patients with allergic asthma. These findings suggest that spleen DCs and Foxp ${ }_{3}{ }^{+}$Tregs prevents the generation and activation of Th2 effector cells as a novel pathway of regulation of type 2 immunity in asthma.

\section{Competing interests}

The authors declare that they have no competing interests.

\section{Authors' contributions}

YL performed all analyses and wrote the initial draft of the paper. XM obtained funding for the project, conceived the question, and directed writing and analysis. YL, GS, XM, CX, and XD participated in funding, data collection, data analysis and interpretation, and editing. J and DP participated in the reversed manuscript. All authors have read and approved the final manuscript.

\section{Acknowledgements}

This project was partly supported by grants from the National Natural Scientific Foundation of China (NSFC 30200120), China Postdoctoral Science Foundation (NO 200902207), the programs of Science and Technology Commission of Shanghai Municipality (08PJ1402900, 08DZ2293104 and 09540702600), Distinguished Professor Grant for Fudan University and Zhongshan Hospital, and Shanghai Leading Academic Discipline Project (T0206, B115).

\section{Author Details}

'Institute of Respiratory Diseases, Xinqiao's Hospital, Third Military Medical University, Chongqing, China, 2Department of Pulmonary Medicine, Zhongshan Hospital, Fudan University, Shanghai, China and ${ }^{3}$ Intensive Care Unit, Daping's Hospital, Third Military Medical University, Chongqing, China

Received: 2 October 2009 Accepted: 24 March 2010

Published: 24 March 2010

\section{References}

1. Navarro RP, Schaecher KL, Rice GK: Asthma management guidelines: updates, advances, and new options. J Manag Care Pharm 2007 13(Suppl 6):S3-11. quiz S12-3

2. Senna G, Ridolo E, Calderon M, Lombardi C, Canonica GW, Passalacqua G: Evidence of adherence to allergen-specific immunotherapy. Curr Opin Allergy Clin Immunol 2009, 9:544-8.

3. Wang Y, Qian G, Wang G, Cheng X, Bai C, Wang X: Potential therapy of Fcantigen combination-encoding DNA vaccination in mouse allergic airway inflammation. Clin Exp Immunol 2008, 154:115-122.

4. Maecker HT, Hansen G, Walter DM, DeKruyff RH, Levy S, Umetsu DT: Vaccination with allergen-IL-18 fusion DNA protects against, and reverses established, airway hyperreactivity in a murine asthma model. J Immunol 2001, 166:959-965.

5. Matsumoto T, Inoue H, Sato Y, Kita Y, Nakano T, Noda N, Eguchi-Tsuda M, Moriwaki A, Kan-O K, Matsumoto K, Shimizu T, Nagasawa H, Sakuda S, Nakanishi Y: Demethylallosamidin, a chitinase inhibitor, suppresses airway inflammation and hyperresponsiveness. Biochem Biophys Res Commun 2009, 390:103-8

6. Underwood S, Foster M, Raeburn D, Bottoms S, Karlsson JA: Time-course of antigen-induced airway inflammation in the guinea-pig and its relationship to airway hyperresponsiveness. Eur Respir J 1995 8:2104-13.

7. Cheng X, Wang C, Qian G, Zhu B: CD80, but not CD86 were up-regulated on the spleen-derived dendritic cells from OVA-sensitized and challenged BALB/c mice. Immunol Lett 2003, 89:31-38.

8. Bousquet J, Demoly P: Specific immunotherapy - an optimistic future. Allergy 2006, 61:1155-1158.

9. Bieber T: Allergen-specific sublingual immunotherapy: less mystic more scientific. Allergy 2006, 61:149-150.

10. Klostermann B, Bellinghausen I, Böttcher I, Petersen A, Becker WM, Knop J, et al:: Modification of the human allergic immune response by allergenDNA-transfected dendritic cells in vitro. J Allergy Clin Immunol 2004 , 113:327-333.

11. Hammad H, Lambrecht BN: Recent progress in the biology of airway dendritic cells and implications for understanding the regulation of asthmatic inflammation. J Allergy Clin Immunol 2006, 118:331-336.

12. Harmjan K, Bart N: Modification of dendritic cell function as a tool to prevent and treat allergic asthma. Vaccine 2005, 23:4577-4588.

13. Raymond Marianne, Rubio Manuel, Fortin Geneviève, Shalaby Karim Hamdy, Hammad Hamida, Bart N: Lambrecht, Marika Sarfati: Selective control of SIRP-a-positive airway dendritic cell trafficking through CD47 is critical for the development of TH2-mediated allergic inflammation. Journal of Allergy and Clinical Immunology 2009, 124:1333-1342

14. Kubo T, Hatton RD, Oliver J, Liu X, Elson CO, Weaver CT: Regulatory T cell suppression and anergy are differentially regulated by proinflammatory cytokines produced by TLR-activated dendritic cells. $\mathrm{J}$ Immunol 2004, 173:7249-7258

15. Boruchov AM, Heller G, Veri MC, Bonvini E, Ravetch JV, Young JW: Activating and inhibitory lgG Fc receptors on human DCs mediate opposing functions. J Clin Invest 2005, 115:2914-2923.

16. Bousquet J, Bieber T, Fokkens W, Humbert M, Kowalski M, Niggemann B, et al:: Themes in Allergy: one year old and moving forward. Allergy 2006, 61:1-2.

17. Belostotsky R, Lorberboum-Galski H: Utilizing Fcepsilon-Bak chimeric protein for studying IgE-FcepsilonRI interactions. Clin Immunol 2004, 110:89-99.

18. Bruhns P, Frémont S, Daëron M: Regulation of allergy by Fc receptors. Curr Opin Immunol 2005, 17:662-669.

19. Schmidt-Weber CB, Blaser K: New insights into the mechanisms of allergen-specific immunotherapy. Curr Opin Allergy Clin Immunol 2005 5:525-530

20. Teixeira FM, Teixeira HC, Ferreira AP, Rodrigues MF, Azevedo V, Macedo GC, et al:: DNA Vaccine Using Mycobacterium bovis Ag85B Antigen Induces Partial Protection against Experimental Infection in BALB/C Mice. Clin Vaccine Immunol 2006, 13:930-935

21. Sawyer RT, Gergen PJ, Minnicozzi M, Plaut M, Dong G, Schwaninger JM, et al:: The future of immunotherapy. Report of a National Institute of Allergy and Infectious Diseases (NIAID), Division of Allergy, Immunology and Transplantation (DAIT) workshop. Allergy 2006, 61:1159-1161.

22. Li R, Yang $X$, Wang L, Liu E: Respiratory syncytial virus infection reversed anti-asthma effect of neonatal Bacillus Calmette-Guerin vaccination in BALB/c mice. Pediatric Research 2006, 59:210-215.

23. Semic-Jusufagic A, Simpson A, Custovic A: Environmental exposures, genetic predisposition and allergic diseases: one size never fits all. Allergy 2006, 61:397-399.

24. Zhang Xun, Lewkowich lan P, Baelder Ralf, Wills-Karp Marsha, Köhl Jörg: $C 5$ a regulates $B 7$ costimulatory molecule expression on distinct pulmonary dendritic cells to protect from type 2 immunity in asthma. Molecular Immunology 2007, 44:264

25. Bayry J, Lacroix-Desmazes S, Kazatchkine MD, Hermine O, Tough DF, Kaveri SV: Modulation of dendritic cell maturation and function by $B$ lymphocytes. J Immuno/ 2005, 175:15-20.

26. Ettmayer P, Mayer P, Kalthoff F, Neruda W, Harrer N, Hartmann G, et al.: A novel low molecular weight inhibitor of dendritic cells and $B$ cells blocks allergic inflammation. Am J Respir Crit Care Med 2006, 173:599-606.

27. Van Rijt LS, Lambrecht BN: Dendritic cells in asthma: a function beyond sensitization. Clin Exp Allergy 2005, 35:1 125-1134 
28. Radhakrishnan S, lijima K, Kobayashi T, Kita H, Pease LR: Dendritic cells activated by cross-linking B7-DC (PD-L2) block inflammatory airway disease. J Allergy Clin Immunol 2005, 116:668-674.

29. Regnault A, Lankar D, Lacabanne V, Rodriguez A, Théry C, Rescigno M, et al:: Fcy receptor-mediated induction of dendritic cell maturation and major histocompatibility complex class I-restricted antigen presentation after immune complex internalization. J Exp Med 1999, 189:371-380

30. Schuurhuis DH, loan-Facsinay A, Nagelkerken B, van Schip JJ, Sedlik C, Melief $C$, et al: Antigen-antibody immune complexes empower dendritic cells to efficiently prime ppecific CD8+ CTL responses in vivo. $\mathrm{J}$ Immunol 2002, 168:2240-2246.

31. Fiset PO, Tulic MK, Skrablin PS, Grover SM, Letuve S, Mazer BD, et al.: Signal transducer and activator of transcription 6 down-regulates toll-like receptor-4 expression of a monocytic cell line. Clin Exp Allergy 2006, 36:158-65.

32. Lemanske RF Jr, Busse WW: Asthma: Factors underlying inception exacebation and disease progression. J Allergy Clin Lmmunol 2006 117(Suppl 2):456-461.

33. Mukai K, Matsuoka K, Taya C, Suzuki H, Yokozeki H, Nishioka K, et al: Basophils play a critical role in the development of IgE-mediated chronic allergic inflammation independently of $T$ cells and mast cells. Immunity 2005, 23:191-202.

34. Kallinich T, Beier KC, Gelfand EW, Kroczek RA, Hamelmann E: Costimulatory molecules as potential targets for therapeutic intervention in allergic airway disease. Clin Exp Allergy 2005, 35:1521-1534.

35. van Rijt LS, Vos N, Willart M, Kleinjan A, Coyle AJ, Hoogsteden HC, et al.: Essential role of dendritic cell CD80/CD86 costimulation in the induction, but not reactivation, of $\mathrm{TH} 2$ effector responses in a mouse model of asthma. J Allergy Clin Immunol 2004, 114:166-173.

36. Keiko Ohga, Sadao Kuromitsu, Ryuichi Takezawa, Mako Numazaki, Jun Ishikawa, Shinya Nagashima, Yasuaki Shimizu: YM-341619 suppresses the differentiation of spleen T cells into Th2 cells in vitro, eosinophilia, and airway hyperresponsiveness in rat allergic models. European Journal of Pharmacology 2008, 590:409-416.

37. Grayson MH: Lung dendritic cells and the inflammatory response. Ann Allergy Asthma Immunol 2006, 96:643-51. quiz 652-3, 678

38. Bharadwaj AS, Bewtra AK, Agrawal DK: Dendritic cells in allergic airway inflammation. Can J Physiol Pharmacol 2007, 85:686-699.

39. Hammad $\mathrm{H}$, Lambrecht $\mathrm{BN}$ : Lung dendritic cell migration. Adv Immunol 2007, 93:265-278

40. Wu K, Bi Y, Sun K, Xia J, Wang Y, Wang C: Suppression of allergic inflammation by allergen-DNA-modified dendritic cells depends on the induction of Foxp3+ Regulatory T cells. Scand J Immunol 2008 67:140-151.

41. Larché M: Regulatory T cells in allergy and asthma. Chest 2007, 132:1007-14.

42. Taube C, Buhl R: Immunomodulation therapy for allergic asthma. What is already possible, what is to come? Dtsch Med Wochenschr 2008, 133:727-32.

doi: 10.1186/1479-0556-8-2

Cite this article as: Wang et al., Protection against the allergic airway inflammation depends on the modulation of spleen dendritic cell function and induction of regulatory T cells in mice Genetic Vaccines and Therapy 2010, 8:2

\section{Submit your next manuscript to BioMed Central} and take full advantage of:

- Convenient online submission

- Thorough peer review

- No space constraints or color figure charges

- Immediate publication on acceptance

- Inclusion in PubMed, CAS, Scopus and Google Scholar

- Research which is freely available for redistribution

Submit your manuscript at www.biomedcentral.com/submit
C Biomed Central 